\title{
Possible Plasmid Nature of the Determinant for Production of the Antibiotic Nisin in Some Strains of Streptococcus lactis
}

\author{
By P. G. FUCHS, JOLANTA ZAJDEL AND W. T. DOBRZAŃSKI \\ Department of Pharmaceutical Microbiology, Institute of Biopharmacy, \\ Medical Academy, Oczki 3, 02-007 Warsaw, Poland
}

(Received I August 1974, revised I7 December 1974)

\section{INTRODUCTION}

During recent investigations into the genetics of lactic streptococci performed in our laboratory, some observations were made which indicated that gene(s) determining the production of the polypeptide antibiotic nisin (Nis) in some strains of Streptococcus lactis may be located on a plasmid (Kozak, Rajchert-Trzpil \& Dobrzański, I973a, 1974). The evidence included (i) the frequent and spontaneous occurrence of stable nisin-negative ( $\mathrm{Nis}^{-}$) clones in populations of some nisin-producing $\left(\mathrm{Nis}^{+}\right)$strains at frequencies of 0.03 to $0.82 \%$ and (ii) an increase in the frequency of stable $\mathrm{Nis}^{-}$clones as a result of growth of some $\mathrm{Nis}^{+}$ strains in the presence of proflavin (Pro), ethidium bromide (EB) or at the elevated temperature of $40^{\circ} \mathrm{C}$. A 5.4- to 95 -fold increase occurred following growth with Pro or EB and a $\mathrm{I} \cdot 4$ - to 20 -fold increase as a result of growth at $40^{\circ} \mathrm{C}$.

We tested for the presence of plasmid DNA in certain of these $S$. lactis nisin-producing strains and in Nis- clones isolated from them after treatment with Pro and EB (Kozak et al. 1973a, 1974).

\section{METHODS}

Organisms. All Streptococcus lactis strains used in the study originated in this laboratory (Kozak et al. 1973a, 1974). The strains and their relevant characters are listed in Table I.

Media. Bacteria were stored at $4{ }^{\circ} \mathrm{C}$ in a $10 \%(\mathrm{w} / \mathrm{v})$ aqueous suspension of powdered skim milk, enriched with $0.5 \%$ yeast extract (Difco). Radioactive labelling of DNA was performed in a semi-synthetic medium (SSM; Parsons et al. 1973). Lactose-fermenting ability was tested using a medium composed of $(\%, w / v)$ : dehydrated meat broth (Biomed, Poland), I; yeast extract (Difco), I; NaCl, I.5; $\mathrm{Na}_{2} \mathrm{HPO}_{4}, 0.5 ; \mathrm{MgSO}_{4} \cdot 7 \mathrm{H}_{2} \mathrm{O}, 0.5$; lactose, I ; bromocresol purple, 0.004; agar, $\mathrm{I} \cdot 5 ; \mathrm{pH} 7 \cdot 2$.

Nisin was determined by the method of Tramer \& Fowler (1964).

Lysogeny was tested using the method of Kozak et al. (1973b).

DNA labelling and preparation of cleared lysates. Samples $(24 \mathrm{ml})$ of SSM supplemented with 2-deoxyadenosine $(250 \mu \mathrm{g} / \mathrm{ml})$ and $\left[{ }^{3} \mathrm{H}\right]$ thymidine $(5 \mu \mathrm{Ci} / \mathrm{ml}$; specific activity $5 \mathrm{Ci} /$ $\mathrm{mmol})$ were inoculated with $3 \%(\mathrm{v} / \mathrm{v})$ of an overnight culture of $S$. lactis in SSM $\left(3 \times 10^{8}\right.$ colony-forming units $/ \mathrm{ml}$ ) and grown for $5.5 \mathrm{~h}$ at $30^{\circ} \mathrm{C}$. Bacteria were collected by centrifugation, washed once with TES buffer $\left(0.03 \mathrm{M}\right.$-tris, $0.005 \mathrm{M}-\mathrm{Na}_{2}-\mathrm{EDTA}, 0.05 \mathrm{M}-\mathrm{NaCl}$, $\mathrm{pH} 8 \cdot 0$ ) and suspended in $2 \mathrm{ml}$ of TES. A portion $(0.4 \mathrm{ml})$ of lysozyme solution $(12 \mathrm{mg} / \mathrm{ml})$ was added and the samples were incubated for $1.5 \mathrm{~h}$ at $37^{\circ} \mathrm{C}$. Lysis was then performed with Brij- 58 by the method of Courvalin, Carlier \& Chabbert (1972). After lysis was completed, samples were centrifuged at $20000 \mathrm{~g}$ for $30 \mathrm{~min}$ at $4{ }^{\circ} \mathrm{C}$ to remove the bulk of the chromosomal DNA. 
Table I. Strains of S. lactis

\begin{tabular}{|c|c|c|c|}
\hline \multirow[b]{2}{*}{$\begin{array}{l}\text { S. lactis } \\
\text { strain no. }\end{array}$} & \multicolumn{2}{|c|}{ Ability to: } & \multirow[b]{2}{*}{ Lysogeny } \\
\hline & $\begin{array}{l}\text { Produce } \\
\text { nisin }\end{array}$ & $\begin{array}{c}\text { Ferment } \\
\text { lactose }\end{array}$ & \\
\hline 2 & + & + & ND \\
\hline 27 & + & + & ND \\
\hline 29 & + & + & ND \\
\hline 40 & + & + & + \\
\hline 45 & + & + & + \\
\hline 49 & + & + & ND \\
\hline $49 / \mathrm{V}$ & + & + & ND \\
\hline $5 I / V$ & + & + & ND \\
\hline $49 / \mathrm{v} /$ Pro $^{*}$ & - & - & ND \\
\hline $49 / \mathrm{v} / \mathrm{EB}^{*}$ & - & - & ND \\
\hline $5 \mathrm{I} / \mathrm{V} / \mathrm{Pro}^{*}$ & - & - & ND \\
\hline $5 \mathrm{I} / \mathrm{v} / \mathrm{EB}^{*}$ & - & - & ND \\
\hline
\end{tabular}

ND, Not detected.

* Clones isolated after treatment of strains $49 / \mathrm{V}$ and $5 \mathrm{I} / \mathrm{V}$ with proflavin or ethidium bromide.

Preparation of the gradients and ultracentrifugation. Cleared lysates were mixed with solid caesium chloride and the refractive indices were adjusted either to $\mathrm{I} \cdot 4024$ ( $\mathrm{CsCl}$ gradients) or to $\mathrm{I} \cdot 3929$ (CsCl-EB gradients). The mixtures were then transferred to centrifuge tubes and $0.05 \mathrm{ml}$ ethidium bromide solution ( $10 \mathrm{mg} / \mathrm{ml}$ ) was added to appropriate gradients immediately before centrifugation. Samples were overlaid with liquid paraffin and centrifugation was performed for $40 \mathrm{~h}$ at $150000 \mathrm{~g}$ in the 65 Ti rotor of a Beckman L2-65B ultracentrifuge at $20^{\circ} \mathrm{C}$. Fractions were collected by puncturing the bottom of the tubes. A ro $\mu \mathrm{l}$ portion of each fraction was then put on to a filter-paper disc (Whatman $3 \mathrm{MM}$ ), washed twice with cold $5 \%(\mathrm{w} / \mathrm{v})$ TCA solution and once with acetone, and dried. Radioactivity was counted with a Packard model 2425 liquid scintillation spectrometer using a Liquifluor scintillation mixture.

Chemicals. [Methyl- ${ }^{3} \mathrm{H}$ ] thymidine was purchased from the Radiochemical Centre, Amersham, Buckinghamshire. Ethidium bromide, Brij-58 and $\mathrm{CsCl}$ (optical grade) were obtained from Serva Feinbiochemica, West Germany, 2-deoxyadenosine from Sigma, proflavin from Loba-Chemie, Austria, and Liquifluor from NEN Chemicals, West Germany.

\section{RESULTS AND DISCUSSION}

As shown in Table $\mathrm{I}$, in four clones derived from strains $49 / \mathrm{V}$ and $5 \mathrm{I} / \mathrm{V}$ loss of the ability to produce nisin as a result of treatment with Pro or EB was accompanied by loss of the ability to ferment lactose.

Cleared lysates of strains were investigated by ultracentrifugation in CsCl-EB gradients (Radloff, Bauer \& Vinograd, 1967) for the occurrence of a more dense fraction of DNA, indicating the presence of covalently closed circular (c.c.c.) DNA characteristic of plasmids.

Among eight $S$. lactis strains tested, six (nos. 27, 40, 45, 49, 49/v and 5I/v) were found to have c.c.c. DNA, but in two strains (nos. 2 and 29) it was not observed. When centrifuging the cleared lysates in a gradient of $\mathrm{CsCl}$ alone, the denser DNA fraction was absent.

Though c.c.c. DNA was not observed in cleared lysates prepared from clones 49/v/Pro and $49 / \mathrm{v} / \mathrm{EB}$, it was detectable in lysates of clones $5 \mathrm{I} / \mathrm{v} /$ Pro and $5 \mathrm{I} / \mathrm{v} / \mathrm{EB}$ (Fig. I). In clone 


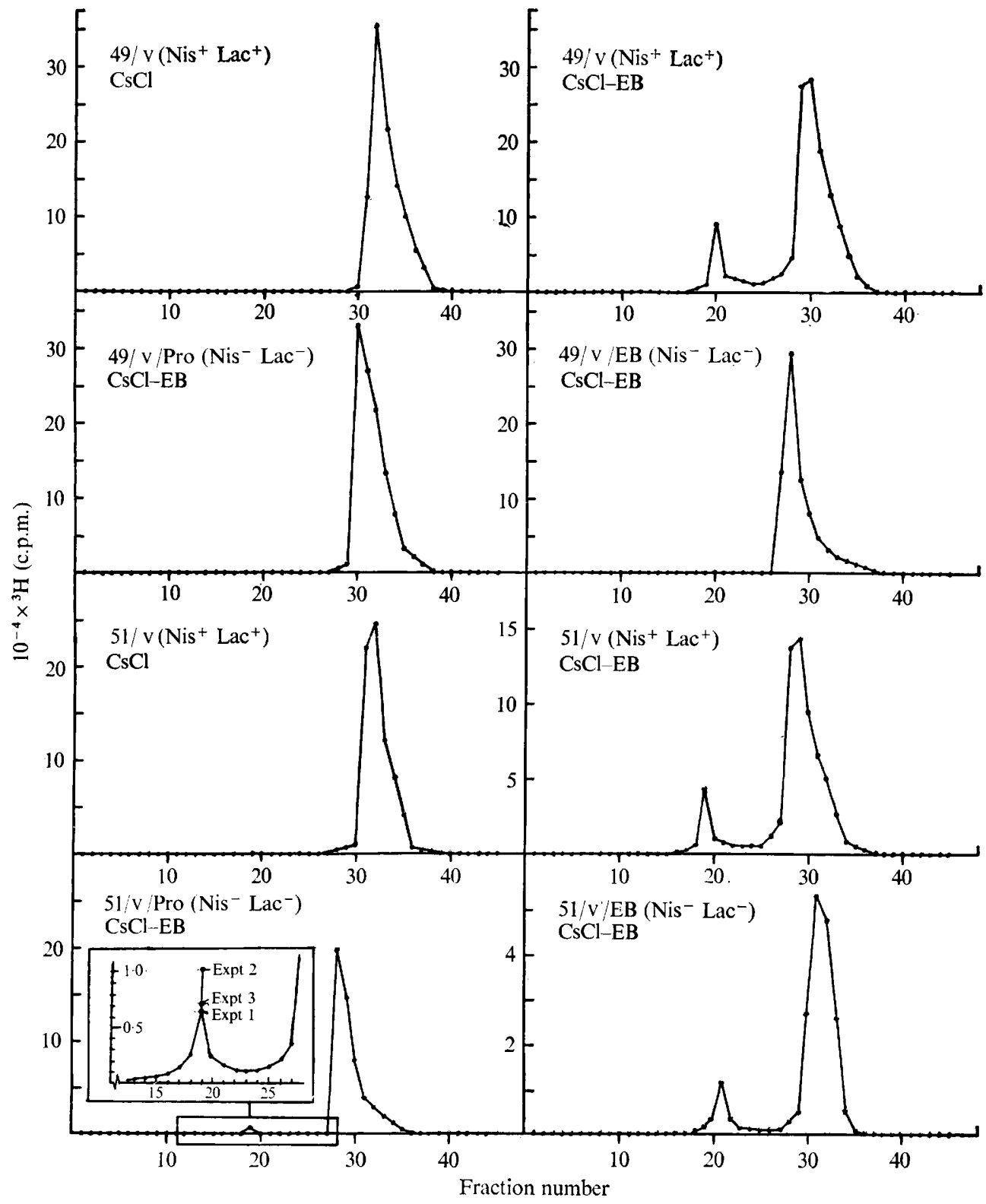

Fig. I. $\mathrm{CsCl}$ and $\mathrm{CsCl}-\mathrm{EB}$ gradient analysis of cleared lysates from $S$. lactis strains $49 / \mathrm{v}, 5 \mathrm{I} / \mathrm{V}$ and $\mathrm{Nis}^{-}$derivatives isolated after proflavin or ethidium bromide treatment.

$5 \mathrm{I} / \mathrm{v} /$ Pro the c.c.c. fraction was very small in comparison with the same fraction in the parental $\mathrm{Nis}^{+}$strain.

The lack of c.c.c. DNA in two of the strains studied (nos. 2 and 29) may indicate the absence of plasmids in these strains or the presence of plasmid material integrated into the bacterial chromosome. Since the majority of the strains tested were non-lysogenic, it is unlikely that that phage genomes contribute to c.c.c. DNA.

The loss of $\mathrm{Nis}^{+} \mathrm{Lac}^{+}$characters in strain $49 / \mathrm{v}$, accompanied by the disappearance of 
c.c.c. DNA, may indicate that genes responsible for these characters are located on a plas$\operatorname{mid}(\mathrm{s})$. However, clones $5 \mathrm{I} / \mathrm{v} /$ Pro and $5 \mathrm{I} / \mathrm{v} / \mathrm{EB}$, although $\mathrm{Nis}^{-} \mathrm{Lac}^{-}$, still contain c.c.c. DNA. The occurrence of a minute c.c.c. DNA peak in clone $5 \mathrm{I} / \mathrm{v} /$ Pro may be characteristic, since it was observed in each of three independent experiments.

The results of Kozak et al. (1974) suggest that (i) ethidium bromide and proflavin are less effective curing agents for strain $5 \mathrm{I} / \mathrm{V}$ than for $49 / \mathrm{V}$, and (ii) in strain $5 \mathrm{I} / \mathrm{V}$ proflavin may be more effective in eliminating the nisin gene(s) than ethidium bromide. Plasmids differ in their susceptibility to various curing agents (Clowes, 1972) and it is possible that in strain $5 \mathrm{I} / \mathrm{V}$ the genes for nisin production and lactose fermentation are located on a plasmid(s) which has been removed by the curing agents, while certain other plasmid DNA remains in the bacterial population.

Since the completion of these experiments, Cords, McKay \& Guerry (1974) have reported the presence of various forms of c.c.c. DNA in different strains of lactic streptococci. They found that $S$. lactis $\mathrm{C} 2$ and a lactose-negative clone isolated from this strain after acriflavine treatment both contained c.c.c. DNA.

Further experiments are necessary to determine the properties of $S$. lactis plasmids. Such experiments are in progress in our laboratory.

This work was supported by The Polish Academy of Sciences within project 09.3.I./I.3.4.

\section{REFERENCES}

Clowes, R. C. (1972). Molecular structure of bacterial plasmids. Bacteriological Reviews 36, 36I-405.

Cords, B. R., MCKay, L. L. \& GuerRY, P. (1974). Extrachromosomal elements in group N streptococci. Journal of Bacteriology II7, I I 49-I I 52.

Courvalin, P. M., Carlier, C. \& Chabbert, Y. A. (1972). Plasmid-linked tetracycline and erythromycin resistance in group D 'Streptococcus'. Annales de l'Institut Pasteur 123, 755-759.

KozAK, W., RAJChERT-TrZPIL, M. \& DobrZAŃSKI, W. T. (1973a). Preliminary observations on the influence of proflavin, ethidium bromide and elevated temperature on the production of the antibiotic nisin by Streptococcus lactis strains. Bulletin de l'Académie polonaise des sciences. Class VI 2I, 8I I-81 7 .

KozAK, W., RAJCHERT-TRZPIL, M. \& DoBRZAŃSKI, W. T. (1974). The effect of proflavin, ethidium bromide and an elevated temperature on the appearance of nisin-negative clones in nisin-producing strains of Streptococcus lactis. Journal of General Microbiology 83, 295-302.

KozAK, W., RaJChert-TrzPIL, M., ZAJDEL, J. \& DobrZaŃSKI, W. T. (1973b). Lysogeny in lactic streptococci producing and not producing nisin. Applied Microbiology 25, 305-308.

Parsons, C. L., Ranhand, J. M., Leonard, C. G., Colon, A. E. \& Cole, R. M. (1973). Inhibition of transformation in group H streptococci by lysogeny. Journal of Bacteriology I13, I217-I 222.

RAdLofF, R., BAUER, W. \& Vinograd, J. (I967). A dye-buoyant-density method for the detection and isolation of closed circular duplex DNA: the closed circular DNA in HeLa cells. Proceedings of the National Academy of Sciences of the United States of America 57, I5I4-1521.

TRAmer, J. \& Fowler, G. C. (1964). Estimation of nisin in foods. Journal of the Science of Food and Agriculture 15, 522-528. 